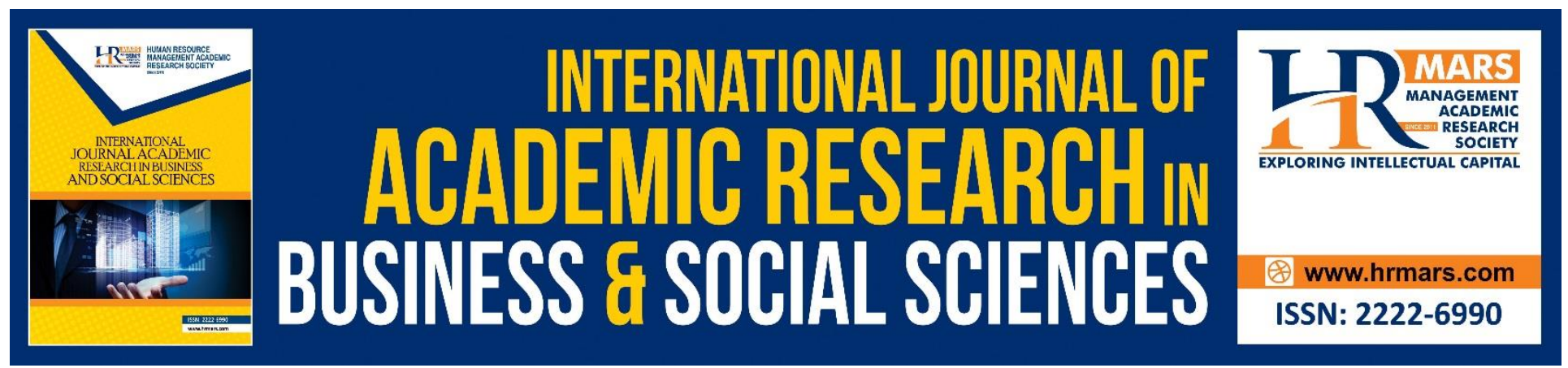

\title{
Systematic Literature Review: Benefits of Fisheries Technology on Small Scale Fishermen
}

Raidah Mazuki, Mohd Nizam Osman, Jusang Bolong and Siti Zobidah Omar

To Link this Article: http://dx.doi.org/10.6007/IJARBSS/v10-i16/8314

DOI:10.6007/IJARBSS/v10-i16/8314

Received: 18 September 2020, Revised: 20 October 2020, Accepted: 16 November 2020

Published Online: 29 November 2020

In-Text Citation: (Mazuki et al., 2020)

To Cite this Article: Mazuki, R., Osman, M. N., Bolong, J., \& Omar, S. Z. (2020). Systematic Literature Review: Benefits of Fisheries Technology on Small Scale Fishermen. International Journal Academic Research in Business and Social Sciences, 10(16), 307-316.

\section{Copyright: () 2020 The Author(s)}

Published by Human Resource Management Academic Research Society (www.hrmars.com)

This article is published under the Creative Commons Attribution (CC BY 4.0) license. Anyone may reproduce, distribute, translate and create derivative works of this article (for both commercial and non-commercial purposes), subject to full attribution to the original publication and authors. The full terms of this license may be seen at: http://creativecommons.org/licences/by/4.0/legalcode

Special Issue: Youth and Community Wellbeing: Issues, Challenges and Opportunities for Empowerment V2, 2020, Pg. 307 - 316

Full Terms \& Conditions of access and use can be found at http://hrmars.com/index.php/pages/detail/publication-ethics 


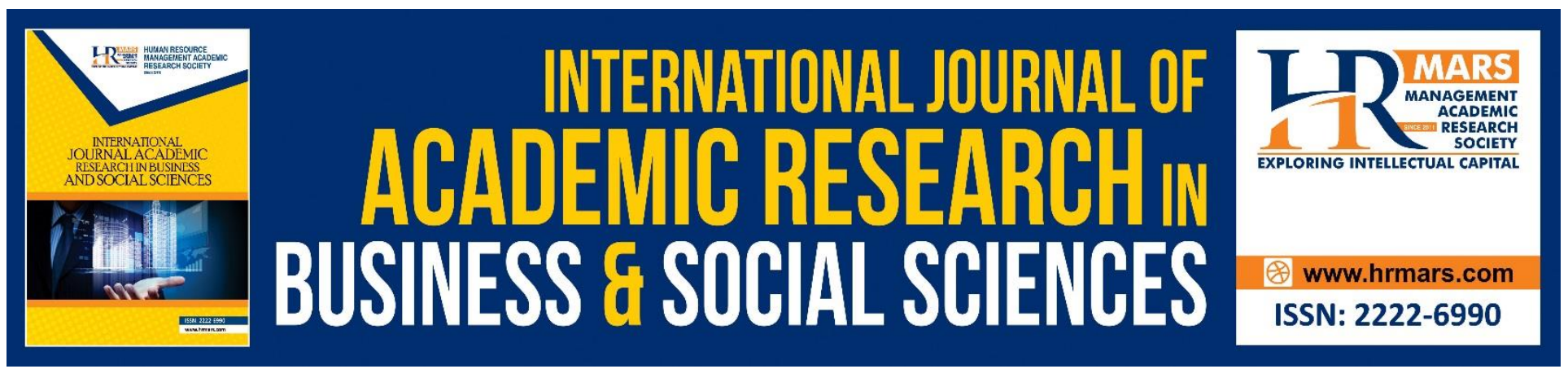

\title{
Systematic Literature Review: Benefits of Fisheries Technology on Small Scale Fishermen
}

\section{${ }^{1}$ Raidah Mazuki, ${ }^{2}$ Mohd Nizam Osman, ${ }^{2}$ Jusang Bolong and ${ }^{1}$ Siti Zobidah Omar}

${ }^{1}$ Institute for Social Science Studies, Putra Infoport, Universiti Putra Malaysia, 43400, UPM Serdang, Selangor, Malaysia, ${ }^{2}$ Faculty of Modern Languages and Communication, Universiti Putra Malaysia, 43400, UPM Serdang, Selangor, Malaysia

Email: raidah0702@gmail.com,mo_nizam@upm.edu.my

\begin{abstract}
Technology usage is a fundamental element in any fishing activity. Small-scale fishermen are often characterized as information-poor and information deprived has always been a central component of rural development initiatives. Thus, this article reviewed the recent studies of fishery technology benefits. This article is based on the conceptual paper approach by reviewing past studies on related issues concerning small scale fishing activities among fishermen using fishing technology. The results showed that there are four benefits of using ICT for fishing activities among small-scale fishermen namely, increase productivity and combat poverty, reduce digital among rural community, improves technology literacy level among rural community, and safety issues among small-scale fishermen. These suggestions are hoped to provide basis for concerned parties to improve their connectivity and disseminate the ICT information and benefit by using the ICT provided in the rural area.
\end{abstract}

Keywords: Small-scale Fishermen, Fisheries Technology, ICT, Communication, Extension, Rural Development

\section{Introduction}

Information and Communication Technology (ICT) is generally defined as a set of equipment that enables to strengthen and accelerate the dissemination and information sharing, facilitate communication process, regardless of geographical characteristics (Meng et al., 2013). The idea of rural development indicates that the desire to improve the conditions and position of rural communities through the recognition on the existence of a dichotomous urban-rural relationship. It is important to study the potential benefits of ICT to improve access to basic human development requirements such as food, education and healthcare. Globally there is a huge disparity in terms of challenges and opportunities between rural development and urban development. Rural development is forced by the need to strengthen the rural objectives to ensure that current rural 
INTERNATIONAL JOURNAL OF ACADEMIC RESEARCH IN BUSINESS AND SOCIAL SCIENCES

Vol. 10, No. 16, Youth and Community Wellbeing: Issues, Challenges and Opportunities for Empowerment V2. 2020, E-ISSN: 2222-6990 @) 2020 HRMARS

disparities will not significantly predicate digital inequalities. In scrutinizing the potential benefits of ICT for rural development, it is indeed necessary to identify and to recognize that information dissemination is a fundamental element of any rural development programme as rural areas are regularly characterized as information-poor (Chapman \& Slaymaker, 2002). Consecutively, issues of sustainability which involve factors of human capacity, social capital and best practice models also highlight the importance of rural communities to optimize the benefits of ICT for rural development.

Abundance of extension methods and strategies depend on technology transfer with top-down development without having a framework for feedback from farmers. Avault et. al (1984) also agreed that any possible rural development program initiated from the top-down without acknowledged that rural areas are perceived to be highly traditional, resistant to change, and unaware of technological advancement (FAO, 2006). Recently, there has been greater participation among the rural community, although it is difficult, especially with a new ICT technology. In developing countries, the majority of rural people are depended on extension agents for advice and for technical information and assistance on agricultural and rural-related development (Shah et. al, 2013). The success of extension services relies on the role of extension officers to transfer technology and technical competence in developing rural community to increase their productivity (Rahim, 2008). According to Sulaiman and Hall (2002); Fadeyi at el (2015) the role of the extension agent is to contribute to capacity development through training, strengthening the innovation process, building linkages between farmers and other agencies, and helping to strengthen farmers' bargaining position through appropriate institutional and organizational development. Doubtlessly, the competency of extension agents in Malaysia as a change agent and one of the important determinants of success for rural community development should not be undermined.

With regards to fishing technology, either in the form of fish-catching technology or for navigational purposes has profoundly altered the relationship between vessels and the shore (Chauvin, Morel \& Tirilly, 2010) by the rapid dissemination and receiving information to any part of the world at any time. Based on the data presented in Table 1, fishing technology is known to increase efficiency and to ease work of the fishermen when they are out at sea. Other than that, ICT allows fishermen to sort their life much better through communication on the phone, computer and internet usage, locate and find aquatic resources via Global Positioning System (GPS) and helps in recording the sale. Despite the explosion of knowledge and technology changes among rural community, small-scale fishermen community in Malaysia appears to be lacking in terms of using the appropriate fishing technology when engaging in fishing activities. There are many potential benefits which are offered by the new and modern fishing technology. Small-scale fisheries are inclined by dynamic climate change, governance, and market drivers, which present social and ecological challenges and opportunities. ICT plays an important role in the development of fishermen. It is necessary to expose the ICT to the rural community especially the small-scale fisherman community. 
INTERNATIONAL JOURNAL OF ACADEMIC RESEARCH IN BUSINESS AND SOCIAL SCIENCES

Vol. 10, No. 16, Youth and Community Wellbeing: Issues, Challenges and Opportunities for Empowerment V2. 2020, E-ISSN: 2222-6990 @ 2020 HRMARS

Table 1: ICT tools functions and benefits for fishermen. (Omar et al., 2011)

\begin{tabular}{|c|c|}
\hline ICT Tools & Functions/benefits \\
\hline $\begin{array}{l}\text { Global } \\
\text { Positioning } \\
\text { System (GPS) }\end{array}$ & $\begin{array}{l}\text { Marking the spots and location of the fish, it can assist fishermen to return } \\
\text { back exactly to the same position whether during daytime or at night. It } \\
\text { provides information such as latitude, longitude, altitude, surface speed, } \\
\text { sunrise and sunset times, odometer and accuracy warning system. }\end{array}$ \\
\hline Sonar & $\begin{array}{l}\text { Through sonar, fishermen can get a complete, immediately up to date, } \\
\text { available map of the whole fishing area showing the exact location, extend, } \\
\text { density, depth, movement, species and size of all fish shoals. In addition, } \\
\text { information regarding sea bottom such as depth, contours, slopes and stones } \\
\text { can easily be gained. }\end{array}$ \\
\hline Echo sounder & Used to measure the depth beneath the vessel or for detecting fish location. \\
\hline Wireless set & $\begin{array}{l}\text { Wireless set enhances the security aspects of the fishermen. If anything } \\
\text { happens to them while at sea, they can communicate with other vessels and } \\
\text { the responsible agencies so that immediate actions can be taken. On top of it, } \\
\text { they can immediately share information regarding the fishing spots with the } \\
\text { others. Moreover, through the use of the wireless set, fishermen can get } \\
\text { better deal and offer for better price with the dealers even when they are still } \\
\text { at sea. }\end{array}$ \\
\hline Computer & $\begin{array}{l}\text { Used for keying in data and record purposes (ex: profit and loss, species } \\
\text { caught, weather condition, markets, etc) }\end{array}$ \\
\hline Mobile phone & $\begin{array}{l}\text { To seek, disseminate and share fisheries related information such as market } \\
\text { price, online applications, weather conditions, professional advices, loan } \\
\text { services, business opportunity, etc among/between colleague and related } \\
\text { agencies. Moreover, through mobile phones, fishermen can deal and can get } \\
\text { better price with the dealers even when they are still at sea. }\end{array}$ \\
\hline
\end{tabular}

\section{Methodology}

The initial step in developing a systematic review paper is very challenging for locating and retrieving the relevant literature. Generally, the literature for this field is scarce, but there are papers from related disciplines which give an overview from the literature within their area. At the early stage, the method and approach of data collection is based on the exploratory approach, especially in exploring related studies in analyzing relationships between fisheries technology and its benefits on small-scale fishermen. The systematic search is conducted with key words and concepts search from academic disciplines. In this stage, relevant articles were sought from SCOPUS search engines as it covers the cross-disciplinary scope of this paper. The following terms were selected for search queries to cover the fisheries technology benefits and small-scale fishermen: "fisheries technology," "fisheries technology benefits," "small-scale fishermen," "ICT," "information technology," and "digital divide." Other than that, to cover the rural advancement component, this paper used the following terminology search: "rural advancement," "rural community," and "rural areas." Searching 
INTERNATIONAL JOURNAL OF ACADEMIC RESEARCH IN BUSINESS AND SOCIAL SCIENCES

Vol. 10, No. 16, Youth and Community Wellbeing: Issues, Challenges and Opportunities for Empowerment V2. 2020, E-ISSN: 2222-6990 @) 2020 HRMARS

with combinations of these 9 terms generated a total of 1020 search queries. As a result, there were 281 articles found in identification; eventually, after the second stage of the screening process, only 34 articles met the criteria with the small-scale fishermen and being published in English-language academic journal. A total of $27.5 \%$ of the articles were related to small-scale fishery and fishery ICT technology usage, while the balance was related to ICT technology usage in general. Four pertinent benefits were highlighted throughout the 34 articles; namely, increase productivity and combat poverty, reduce digital divide among rural community, improves rural community technology literacy level, and small-scale fishermen community safety.

\section{Benefits of fisheries technology}

Increase productivity and combat poverty

Since achieving independence in 1957, Malaysia has successfully transformed itself from a poor country to a middle-income country. The incidence of poverty has been drastically reduced from $49.3 \%$ in 1970 to only $3.8 \%$ in 2010 , with hardcore poverty nearly eradicated, declining to $0.7 \%$ in 2009 (Abidin \& Rasiah, 2009). Malaysia's real Gross Domestic Product (GDP) has grown by an average of 5.8\% per annum from 1991 to 2010 (Economic Planning Unit, 2010). The World Bank defines poverty in absolute terms. The bank defines extreme poverty as living on less than US\$1.90 per day (United Nations (UN), 2016).The pledge to leave no one behind relates closely to three important dimensions of the 2030 Agenda: poverty, inclusiveness and inequality. Fishing communities are often categorized by overcrowded and sub-standard living conditions, low levels of education, and poor access to services like schools, health care, and infrastructure such as roads or markets. Despite the natural resources, Lawson et. al (2012) has emphasized that, the poverty of fishing communities is dependent upon income and unemployment.

In Malaysia, each registered fisherman receives a monthly allowance of about RM 300 and daily fuel subsidy in the amount of RM45. This allowance is primarily aimed at reducing the daily burden of the small-scale fishermen, yet, it is still seen as insufficient. The poverty level among fishermen has reached a critical level (Solaymani \& Kari, 2014). This is due to the climate change that has distracted the fishermen daily activities, especially when undertaking fishing activities and has resulted to productivity declining. Hence, to encounter this problem, it is vital to use the fishing technology such as GPS, mobile phone and echo sounder when undertaking fishing activities at sea. Echo sounder function is to detect a school of fish movement and a coral reef that may damage the fishing net. Moreover, GPS will help to mark the spots where the fish are. Then, this information can be disseminated to others by using mobile phone. This approach generally help the fishermen to increase their productivity by strategizing their daily fishing trips even during the monsoon seasons. Profitability in small-scale fisheries depends on many factors such as the number/amount of landings in the region, seasons, tools used, and sometimes the daily catch Moreover, ICT tools such as computer and internet will encourage e-entrepreneurship among its users to be involved in business activities which will further increase their living quality (Rao, 2004; Norizan, 2009; Ahmad et al., 2009) Furthermore, the mobile phone can assist in promoting the fish production to the regular customer or middle person although they are still at sea. The updated price, size and types of fish that already caught earlier can be informed through the use of this technology rapidly. Thus, the fishermen can do the reservation based on the customer or middle person requests. Fishermen either sell their catch selectively, usually at a good price, to customers awaiting them or wait for a trucker to sell the 
INTERNATIONAL JOURNAL OF ACADEMIC RESEARCH IN BUSINESS AND SOCIAL SCIENCES

Vol. 10, No. 16, Youth and Community Wellbeing: Issues, Challenges and Opportunities for Empowerment V2. 2020, E-ISSN: 2222-6990 @) 2020 HRMARS

entire lot collectively, at a relatively lower price, within a couple of hours after landed. This strategy would help the small-scale fishermen to estimate their daily catch and prepare themselves when facing the monsoon season or any other forms of emergency situation. On the other hand, according to Allison \& Ellis (2001) rather than monitoring 'how many' fish are caught, these scholars proposed that the best option is to advance fishing limits that affect 'how, when and where, fish are caught', to ensure that primary environment functions that support fisheries productivity are preserved.

The small-scale fishermen highly recommended to utilize the fishery technology equipment to develop living strategies and improve their living quality subsequently, thus, reducing the poverty level (Lee et. al, 2014; Saville, Riani, \& Hatanaka, 2015). Poor small-scale fishermen in developing countries who have limited resources and scarce access to markets and information meet major constraints in the adoption of technological innovations and may therefore be excluded from trade (Ruben, Slingerland, \& Nijhoff, 2006). By promoting the benefits of fishery technology, it would change the normal social traditions, cultural constraints, and conservative attitudes that differentiate against fishermen and limit their accessibility to economic resources and opportunities (Yahaya, 2001).

\section{Reduce digital divide among rural community}

Digital inequality is one of the most topic of concern in the "information age". A few studies have been found and observed which address the social inequality in information resources and digital use patterns (Yu, Lin, \& Liao, 2017). In the rural areas, such ICT facilities could not guarantee that users can easily access information technology and overcome the so-called "digital divide." Digital information and communication technologies (ICTs) have continued to advance rapidly. All parts of the world are now major users. Yet, while some digital gaps have closed, others are continuing to be exposed with the overview of new technologies. It also recognizes that the extensive development benefits from using these technologies have lagged behind (United Nations (UN), 2016). Thomas et. al (2016) noted that this was expected because of the digital divide between urban areas and rural areas are based within the town centers of rural areas that have better Internet access than who generally reside further from urban areas.

Small-scale fishermen contribute between 50 and 70 percent of the Malaysian protein supply (LKIM, 2016). However, in rural areas, small-scale fishermen ineffectively use information in their business and have inadequate information for decision making as a result of the digital divide and information asymmetry in the fishery sector. Such phenomena can be due to the lack of the application of fishery technology in the field of fishing information management (Raungpaka \& Savetpanuvong, 2017). The education level of participants influenced the use of fishery technologies (Hoffman et. al., 2000; Omar et. al, 2011; Wright, Hammond, Thomas, MacLeod, \& Abbott, 2018).

The small-scale fishermen are still unable to take full advantage of the information and technology resources that could very well help to increase their socio-economic status (Alam and Imran, 2015). Rural partnership development would share the benefits of fishery technology usage among smallscale fishermen through high speed and wider coverage of internet. Usually, older generation and more senior fishermen are usually seen as reluctant to use ICTs for their fishing activities because they usually tend to rely more on the vast experience and personal instinct when undertaking fishing activities at sea. In order to manage this issue, there is a need for the younger generation in the community to share their knowledge and expertise to the older generation in using sophisticated 
INTERNATIONAL JOURNAL OF ACADEMIC RESEARCH IN BUSINESS AND SOCIAL SCIENCES

Vol. 10, No. 16, Youth and Community Wellbeing: Issues, Challenges and Opportunities for Empowerment V2. 2020, E-ISSN: 2222-6990 @) 2020 HRMARS

technologies when undertaking fishing activities. The younger generation is prone to be more adaptable in using newer and more sophisticated innovation of the technology.

\section{Improved Rural Community Technology Literacy Level}

Technology literacy in small-scale fishermen situations is defined as the ability to effectively use fishing technology or any tool, piece of equipment or device, electronic or mechanical) to accomplish required learning tasks (Davies, 2011). Technology literate small-scale fishermen know what the technology is capable of, they are able to use the technology proficiently, and they make quick and wise decisions about which fishery technology to use and when to use it. Assessing the highest levels of technology literacy requires something more than evidence of knowledge and use.

Numerous ICTs benefits have been explored by diverse researchers in relation to rural community literacy in using sophisticated fishing-related technologies and its relationship with lower level of education and literacy rate in the society. Access to ICTs is not only playing a gradually essential role in education but in the daily lives of small-scale fishermen community as well. Small-scale fishermen must become alert concerning the availability of fishing technology and its basic purpose, then implement and practice it in authentic situations if they are to reach the higher levels of technology literacy. Extension agent plays an important role to manage and to gradually overcome this issue. They were just not only a consultant of the new technology but also a teacher for the community. They have to ensure that the community would be able to develop their knowledge instead of skills. As their fishery technology literacy develops, small-scale fishermen are able to explain how a specific technology may be used to accomplish tasks. It is a basic role in terms of technology adoption and usage in rural societies. Literate community would be able to focus on raising healthier families and enhance their socio-economic level at the end. Technology has altered all aspects of society, including the teaching-learning process (Resta \& Laferrière, 2015).

\section{Small-scale Fishermen Community Safety}

Safety at sea is another area of concern for the small-scale fishing industry (Håvold, 2010; Belwal et.al., 2014). Bad weather and rough seas combined with engine breakdown are often common factors faced by small-scale fishermen. Some incidents of falling overboard may be the result of waves, trip, and a slippery boat deck, entanglement in fishing equipment and others (Aasjord, 2006). Håvold, 2010 noted that younger generation are more prone to face accidents when they are out at sea probably because more senior fishermen have more on-the-job experience and have greater work knowledge, patience, and skills as compared to their younger counterparts. It is also due to the scarcity of fish near to the shore, the younger generation generally prefer deep sea fishing, possibly for an overnight stay. However, they encountered problems and challenges including carrying enough fuel, food and water supply, and other required necessities for their safety. In order to articulate effective interventions to improve safety, a comprehensive understanding of both the nature of safety and lack of it is essential. Other than that, the influence of family plays a major role for the small-scale fishermen in using the technology associated with fishing when they are out at sea. By having more than one family members working in fishing industry, this can have a positive significant influence towards the usage of fishing technologies for fishing related activities out at sea.

The fishing technology such as a stable boat or vessel, navigational aids and communication facilities can save the lives of many fishermen. Furthermore, small-scale fishermen do not go deep out into 
INTERNATIONAL JOURNAL OF ACADEMIC RESEARCH IN BUSINESS AND SOCIAL SCIENCES

Vol. 10, No. 16, Youth and Community Wellbeing: Issues, Challenges and Opportunities for Empowerment V2. 2020, E-ISSN: 2222-6990 @) 2020 HRMARS

the sea, for they are either worried about getting lost or afraid of being out of the Malaysian Exclusive Economic Zone waters which can get them into trouble with the law. Saville et al, 2015 also agreed that mobile phones can be a very useful communication tool in terms of improving the lives of smallscale fishermen in coastal areas economically, particularly, in sharing information between fishermen, for marketing of their fishing products and during an emergency situation when they are out fishing.

Additionally, the weather alerts that appear on local TV, radio, newspaper and internet is another important source of information for the local fishermen when they are out at sea engaging in their fishing activities. The small-scale fishermen also would gain the weather information from other sources, such as contact with government offices, personal calls or SMS, the Internet, and weather advisory assistance which are issued by the meteorological department. ICT tools such as wireless set, mobile phones and GPSs can be used to communicate with their colleagues and agencies officers during emergency. Immediate actions can be taken by their colleagues or the officers in charge to provide help and assistance to the fishermen. Besides marking the fishing location for the fishermen, GPS can also be used to provide useful information to the fishermen on matters such as the threat of coral reefs which can cause significant damages to the fishermen's boat and avoid any accidents that might involve human life. During bad weather, the use of the GPS is also helpful in assisting the fishermen to find their way back.

\section{Conclusion and Recommendations}

The strategic use of ICT related technologies for fishing activities among fishermen as a means of communication tool to communicate over many kinds of information like tides and appropriate fishing strategy, new fishing techniques and practices, government announcement, news sharing, and more. The main worries related to small-scale fishermen with low levels of income, literacy, education, productivity, participation in training and development, and the vulnerabilities caused mainly by scanty fish landings on the coast, lack of operational efficiencies and established supply chain mechanisms, and the widening gaps between traditional and modern fishermen and their techniques. In the overall small scale fishing situation, the significant decrease in the number of fishing activities, the low income and skill levels and their impact on fishermen's productivity and savings, and operational inefficiencies are not a typical finding. Thus, the community need to have more information and knowledge in order to improve their fishery practices. Information exchange among small- scale fishermen community and important shareholders should be improved through mobile and social network technologies given that real experts should help facilitate and diffuse such things into the daily use of fishing related technologies among small-scale fishermen. These can be achieved through multidisciplinary research efforts among government institutes, industries, and universities. Other than that, the related agency need to do a demonstration and courses for the targeted group. This could be one of the best effort in information exchange related to fishery technologies.

\section{References}

Aasjord, H. L. (2006). Tools for improving safety management in the Norwegian fishing fleet. Occupational accidents analysis-period of 1998-2006. International maritime health, 57(1-4), 76-84. 
INTERNATIONAL JOURNAL OF ACADEMIC RESEARCH IN BUSINESS AND SOCIAL SCIENCES

Vol. 10, No. 16, Youth and Community Wellbeing: Issues, Challenges and Opportunities for Empowerment V2. 2020, E-ISSN: 2222-6990 @) 2020 HRMARS

Abidin, M. Z., \& Rasiah, R. (2009). The global financial crisis and the Malaysian economy: Impact and responses. UNDP. Retrieved from http://www.undp.org.my

Ahmad, A. R., Abidin, N. Z., Badusah, J., \& Wai, P. S. (2009). Computer usage and achievement among adults in rural area Malaysia. Journal of Social Sciences, 1.

Alam, K., \& Imran, S. (2015). The digital divide and social inclusion among refugee migrants. Information Technology \& People.

Allison, E. H., \& Ellis, F. (2001). The livelihoods approach and management of small-scale fisheries. Marine policy, 25(5), 377-388.

Avault, J. J. W., Pollock, B. A., Collazo, J. A., Romaire, R. P., \& Cange, S. W. (1984). Evaluating experimental crawfish baits.

Belwal, R., Belwal, S., \& Al Jabri, O. (2014). Training needs assessment of fishermen in Oman through concept mapping technique. European Journal of Training and Development.

Chapman, R., \& Slaymaker, T. (2002). ICTs and rural development: review of the literature, current interventions and opportunities for action. Overseas Development Institute (ODI).

Chauvin, C., Morel, G., \& Tirilly, G. (2010). The use of information and communication technology in the sea fishing industry. Behaviour \& information technology, 29(4), 403-413.

Davies, R. S. (2011). Understanding technology literacy: A framework for evaluating educational technology integration. TechTrends, 55(5), 45.

Fadeyi, O., Oke, A. O., Adegbuyi, A., Ajagbe, M. A., \& Isiavwe, D. T. (2015). Impact of Youth Entrepreneurship in Nation Building. International Journal of Academic Research in Public Policy and Governace, 2(1), 27-39.

FAO, E. (2006). World agriculture: towards 2030/2050. Interim report, Rome.

Håvold, J. I. (2010). Safety culture aboard fishing vessels. Safety science, 48(8), 1054-1061.

Hoffman, D. L., Novak, T. P., and Schlosser, A. (2000), The Evolution of the Digital Divide: How Gaps in Internet Access May Impact Electronic Commerce. Journal of Computer-Mediated Communication, 5: 0. doi:10.1111/j.1083-6101. 2000.tb00341.x

Lawson, E. T., Gordon, C., \& Schluchter, W. (2012). The dynamics of poverty-environment linkages in the coastal zone of Ghana. Ocean \& Coastal Management, 67, 30-38.

Lee, H. W., Sabudin, M., Idrus, R., Osman, M. A., Kruahong, T., \& Leanjay, N. (2014). Exploring the Key Determinants of Successful ICT Innovation Adoption: A Case Study of a Fishing Community in Thailand. In Advances in Computer Science and its Applications (pp. 643-648). Springer, Berlin, Heidelberg.

Meng, C. C., Samah, B. A., \& Omar, S. Z. (2013). A review paper: Critical factors affecting the development of ICT projects in Malaysia. Asian Social Science, 9(4), 42.

Norizan, A. R. (2009). Empowering the rural communities via the telecentres. European Journal of Social Sciences, 9(3), 425-432.

Omar, S. Z., Hassan, M. A., Shaffril, H. A. M., Bolong, J., \& Drsquo, J. L. (2011). Information and communication technology for fisheries industry development in Malaysia. African Journal of Agricultural Research, 6(17), 4166-4176.

Rahim, M. S. (2008). Kompetensi dan Amalan Pendidikan Pengembangan (Concept and Practice of Extension Education). Buletin Pengembangan (Extension Bulletin), Bil, 1.

Rao, S. S. (2004). Role of ICTs in India' s rural community information systems. Journal of information, 6 (4): 261-269 
INTERNATIONAL JOURNAL OF ACADEMIC RESEARCH IN BUSINESS AND SOCIAL SCIENCES

Vol. 10, No. 16, Youth and Community Wellbeing: Issues, Challenges and Opportunities for Empowerment V2. 2020, E-ISSN: 2222-6990 @) 2020 HRMARS

Raungpaka, V., \& Savetpanuvong, P. (2017). Information orientation of small-scale farmers' community enterprises in Northern Thailand. Journal of Social Sciences, 38(3), 196-203. https://doi.org/10.1016/j.kjss.2016.08.018

Resta, P., \& Laferrière, T. (2015). Digital equity and intercultural education. Journal of Education and Information Technologies, 20(4), 743-756. https://doi.org/10.1007/s10639-015-9419-z

Ruben, R., Slingerland, M., \& Nijhoff, H. (2006). Agro-food chains and networks for development: Issues, approaches and strategies. Frontis, 14,1e25. 14,1-25.

Saville, R., Riani, E., \& Hatanaka, K. (2015). The role of mobile phone among small scale fishermen for life improvement and community support tool in Indonesian coastal area. Aquaculture, Aquarium, Conservation \& Legislation International Journal of the Bioflux Society, 8(6), 846-854. Retrieved from http://www.bioflux.com.ro/aacl

Shaffril, H. A. M., Abu Samah, A., \& D'Silva, J. L. (2017). Adapting towards climate change impacts: Strategies for small-scale fishermen in Malaysia. Marine Policy, 81(March), 196-201. https://doi.org/10.1016/j.marpol.2017.03.032

Shah, J. A., Asmuni, A., \& Ismail, A. (2013). Roles of Extension Agents Towards Agricultural Practice in Malaysia. International Journal on Advanced Science, Engineering and Information Technology, 3(1), 59-63.

Solaymani, S., \& Kari, F. (2014). Poverty evaluation in the Malaysian Fishery Community. Ocean and Coastal Management, 95, 165-175. https://doi.org/10.1016/j.ocecoaman.2014.04.017

Sulaiman, V. R., \& Hall, A. (2002). Beyond technology dissemination: reinventing agricultural extension. Outlook on Agriculture, 31(4), 225-233.

The Economic Planning Unit, Malaysia. (2010). Tenth Malaysia plan 2011-2015. The Economic Planning Unit, Prime Minister`s Department, Putrajaya: Malaysia.

Thomas, J., Barraket, J., Ewing, S., MacDonald, T., Mundell, M., Tucker, J. (2016). Measuring Australia's Digital DIvide: The Australian Digital Inclusion Indext 2016. Swinburne University, Melbourne.

United Nations (UN). (2016). Global Sustainable Development Report, 134. Retrieved from https://sustainabledevelopment.un.org/content/documents/2328. Global Sustainable development report 2016 (final).pdf

Wright, D., Hammond, N., Thomas, G., MacLeod, B., \& Abbott, L. K. (2018). The provision of pest and disease information using Information Communication Tools (ICT); an Australian example. Journal of Crop Protection, 103, 20-29. https://doi.org/10.1016/j.cropro.2017.08.023

Yahaya, J. (2001). Women in small-scale fisheries in Malaysia. In: Williams, Meryl J., Mudnakudu Channabsappa Nandeesha, Corral, Violetta P., Tech, Elsie, Sze, Choo Poh (Eds.), International Symposium on Women in Asian Fisheries: Fifth Asian.

Yu, T.-K., Lin, M.-L., \& Liao, Y.-K. (2017). Understanding factors influencing information communication technology adoption behavior: The moderators of information literacy and digital skills. Computers in Human Behavior, 71, 196-208. https://doi.org/10.1016/j.chb.2017.02.005 